\title{
Possibilities of reducing amounts of vicine and convicine in faba bean suspensions and sourdoughs
}

\author{
Marjo Pulkkinen ${ }^{1} \cdot$ Rossana Coda $^{1,2} \cdot$ Anna-Maija Lampi ${ }^{1} \cdot$ Jutta Varis $^{1} \cdot$ Kati Katina $^{1} \cdot$ Vieno Piironen $^{1}$
}

Received: 29 December 2018 / Revised: 5 March 2019 / Accepted: 13 April 2019 / Published online: 3 May 2019

(c) The Author(s) 2019

\begin{abstract}
Vicine and convicine may be removed from faba bean by hydrolysis to the corresponding aglycones, divicine and isouramil. For total elimination of their toxicity, further degradation of the aglycones should be shown. The aim of the study was to investigate hydrolysis of vicine and convicine using the enzymatic activity in faba bean in flour suspensions and selected lactic acid bacteria used as starters for faba bean fermentation. In addition, the effect of acidity on the stability of vicine and convicine was investigated. Sourdoughs were used in a baking process to obtain breads as final products. Vicine, convicine, and their aglycones were analyzed using reversed phase high pressure liquid chromatography with UV detection (RP-HPLCUV). Incubation of the suspensions showed rather small vicine and convicine losses. Acidity itself did not cause losses under the conditions studied, apart from that of convicine at low $\mathrm{pH}$. In sourdough fermentation with strains of Lactobacillus plantarum and Pediococcus pentosaceus, losses of vicine and convicine were dependent on the fermentation temperature and the $\beta$-glucosidase activity of the starter. Compared to fermentation at $20^{\circ} \mathrm{C}$, more intense acidification at $25^{\circ} \mathrm{C}$ resulted in decrease of vicine up to $85 \%$ and convicine up to $47 \%$. Levels of vicine and convicine in breads were comparable to levels in sourdoughs. Furthermore, the aglycones were not detected from breads.
\end{abstract}

Keywords Vicine $\cdot$ Convicine $\cdot$ Hydrolysis $\cdot$ Aglycones $\cdot$ Fermentation $\cdot$ HPLC

\section{Introduction}

Grain legumes have been minor crops among the high-yield cereals and oilseeds that have notable fertilizer requirements. Alternatives for imported soybean are needed, and grain legumes, including pea, faba bean, lupine and lentil could be grown locally in Europe [1]. Faba bean has a high protein yield and an acceptable yield stability compared to other protein-rich crops [1]. There is growing interest in plantbased proteins in human nutrition [2]. Addition of faba bean flour to cereals can increase their protein content and supplement nutritional quality by, for example, complementing the amino acid profile.

Faba bean contains certain harmful compounds that have not been reduced notably via plant breeding [3, 4].

Marjo Pulkkinen

marjo.pulkkinen@helsinki.fi

1 Department of Food and Nutrition, University of Helsinki, Agnes Sjöbergin Katu 2, P.O. Box 66, 00014 Helsinki, Finland

2 Helsinki Institute of Sustainability Science, Helsinki, Finland
The pyrimidine glycosides, vicine and convicine, are under particular observation, since they cause hemolytic anemia called favism for people who have genetic deficiency of the glucose-6-phosphate dehydrogenase (G6PD)-enzyme [5, 6]. Vicine and convicine are hydrolyzed to their corresponding reactive aglycones, divicine and isouramil, which have strong oxidative capacity [7]. Practical processing methods for their removal should be applied, yet they are relatively heat stable, and their complete removal is challenging $[8,9]$.

As one approach, vicine and convicine are hydrolyzed to aglycones using endogenous or added $\beta$-glucosidase enzyme or using fermentation with microbes that are able to synthesize this enzyme [10-14]. When the toxic aglycones are released, they are supposed to react and decompose rapidly due to their instability and thus lose their toxicity [15-18]. The potential of the $\beta$-glucosidase from almonds to hydrolyze vicine and convicine in food systems has been demonstrated in earlier studies [10, 12]. In suspensions, the aglycones were almost completely lost in $2 \mathrm{~h}$ at $\mathrm{pH} 5$ and $37{ }^{\circ} \mathrm{C}$ with added $\beta$-glucosidase [12]. In addition to the $\beta$-glucosidases ( $\beta$-D-glucoside glucohydrolase, EC 3.2.1.21), acidity has been suggested as inducing hydrolysis of the 
$\beta$-glycosidic bond of vicine and convicine, especially when heated to $100{ }^{\circ} \mathrm{C}[17]$.

Endogenous $\beta$-glucosidases participate in many reactions in plants, e.g., they hydrolyze glycosides liberating the active forms in plant defense mechanisms $[19,20]$, and have a role in cellulolysis [21]. Nevertheless, the role of the $\beta$-glucosidases in faba bean, as well as their activity toward vicine and convicine, is rather unclear. Arese and De Flora [22] stated in a review that hydrolysis of vicine and convicine can occur in faba bean seeds by endogenous $\beta$-glucosidase, even though the efficacy of it was not studied. Rizzello et al. [13] measured the $\beta$-glucosidase activity of faba bean doughs using the commonly used artificial $p$-nitrophenyl- $\beta$-D-glucopyranoside (pNPG) substrate, but not using vicine or convicine.

Many strains of lactic acid bacteria (LAB), including Lactobacillus plantarum, Lactobacillus brevis, Pediococcus pentosaceus, and Oenococcus oeni, are capable of producing $\beta$-glucosidase in fermenting cereals, legumes, milk products, and fruits [14, 23-26]. The applicability of substrates is often broad, even though the activities toward different substrate structures may vary [25, 27, 28]. Vicine and convicine were almost completely lost in faba bean suspensions inoculated with Fusarium graminearum $\left(25^{\circ} \mathrm{C}\right.$ for $\left.72 \mathrm{~h}\right)$ or L. plantarum $\left(30^{\circ} \mathrm{C}, 48 \mathrm{~h}\right)$ [11] and in faba bean sourdoughs $\left(30{ }^{\circ} \mathrm{C}, 48 \mathrm{~h}\right.$ ) inoculated with $L$. plantarum B24W [13, 14], most likely because of $\beta$-glucosidase producing bacteria. In addition to its positive effects on hydrolysis of vicine and convicine, LAB fermentation can increase the nutritional quality of faba bean and improve sensory perceptions of the bean [14, 29]. Composite wheat bread containing 30\% faba bean sourdough showed better nutritional quality of the proteins than breads containing $30 \%$ non-fermented faba bean or those made with wheat flour only [30].

However, hydrolysis of vicine and convicine should be carried out in fermentation conditions that are mild enough to attain acceptable technological and sensory properties for baking. In earlier studies, fermentation with $L$. plantarum B24W at $30{ }^{\circ} \mathrm{C}$ for $48 \mathrm{~h}$ effectively hydrolyzed vicine and convicine, but the suitability of the obtained sourdough for baking was not tested $[13,14]$. In addition, the presence and stability of aglycones in bread are poorly understood. There are indications that the aglycones were present and unstable in faba bean paste and sourdoughs [10,13], yet the confirmation is still needed.

The main aim of the present study was to investigate hydrolysis of vicine and convicine using the endogenous $\beta$-glucosidase of faba beans in suspensions and fermentation with selected LAB possessing $\beta$-glucosidase activity in sourdoughs. Furthermore, the stability of the vicine and convicine in an acidic medium was tested. The changes in vicine and convicine levels were investigated under various incubation conditions relevant to food processes and as part of the baking process with the addition of sourdough. Wheat composite breads containing 30\% of fermented faba bean were prepared as final products. To evaluate the total elimination of vicine and convicine more specifically, their aglycone forms were also analyzed in the baking process.

\section{Materials and methods}

\section{Hydrolysis of vicine and convicine in suspensions}

\section{Materials}

Selected faba bean cultivars were used to prepare suspensions to study the effect of endogenous $\beta$-glucosidase activity (Table 1). The faba beans were grown at Viikki Research Farm at the University of Helsinki, which is in southern Finland. In addition, a commercial faba bean flour from Cereal Veneta (San Martino di Lupari, PD, Italy) was used.

The effect of the incubation conditions ( $\mathrm{pH}$, temperature) was tested on two flours (cultivar Kontu and Italian flour) for a 4 and $24 \mathrm{~h}$ incubation period (Table 1). After selecting the incubation conditions, faba beans from four cultivars (Alexia, CDC Fatima, Kontu, and CDC SSNS-1) from 2 years $(2011,2015)$ were studied to compare the activities of endogenous $\beta$-glucosidase among different faba bean cultivars (Table 1).

All the faba bean samples from Finland were milled to particle size of $0.5 \mathrm{~mm}$ using a Centrifugal Mill ZM200 (Retsch, Haan, Germany) without dehulling first. The Italian beans were dehulled and stone-milled. The flour contained $36 \mathrm{~g}$ of protein of dry matter (DM) [30]. The faba beans grown in Finland in 2009-2012 contained an average of $32 \mathrm{~g}$

Table 1 Introduction of experimental conditions and flours used in incubations of suspensions to study endogenous $\beta$-glucosidase activity of faba bean

\begin{tabular}{|c|c|c|c|}
\hline Experiment & Time (h) & Conditions & Flours \\
\hline \multirow[t]{2}{*}{ Effect of $\mathrm{pH}$ and temperature } & 4 & $\begin{array}{l}\text { pH } 4.5,5 \text { and } 6.5 \text { at } 30^{\circ} \mathrm{C} \text {; } \\
\text { pH } 5 \text { at } 37{ }^{\circ} \mathrm{C}\end{array}$ & Cultivar Kontu 2011, Italian flour (2014) \\
\hline & 24 & $\mathrm{pH} 1,2,4.5$ and 5 at $37^{\circ} \mathrm{C}$ & Cultivar Kontu 2015, Italian flour (2014) \\
\hline Cultivar comparison & 4 & $\mathrm{pH} 5,37^{\circ} \mathrm{C}$ & Four cultivars from 2 years (2011 and 2015) \\
\hline
\end{tabular}


of protein of DM [31]. The moisture content of the flours was measured in duplicate according to the AACC method 44-15A [32], and the moisture contents were used to calculate the results on a DM basis.

\section{Incubation experiments}

First, the effects of $\mathrm{pH}$ and temperature were studied in suspensions of $0.5 \mathrm{~g}$ of flour, with $5 \mathrm{ml}$ of two $0.1 \mathrm{M}$ sodium acetate buffers ( $\mathrm{pH} 4.5$ and $\mathrm{pH}$ 5), and Milli-Q water (pH 6.5) (Millipore Corporation, Bedford, MA, USA) at $30{ }^{\circ} \mathrm{C}$ (Table 1). The suspension in buffer at $\mathrm{pH} 5$ was also tested at $37^{\circ} \mathrm{C}$. This short incubation was conducted for $4 \mathrm{~h}$ in a shaking water bath. Next, longer incubations $(24 \mathrm{~h})$ were conducted at $\mathrm{pH}$ values 4.5 and 5 and at low $\mathrm{pH}$ values ( 1 and 2) at $37{ }^{\circ} \mathrm{C}$ (Table 1). For the low $\mathrm{pH}$ values, hydrochloric acid was used as diluted solutions ( $0.1 \mathrm{~N}, 0.01 \mathrm{~N})$. Finally, to enable comparison of the selected cultivars, incubations were conducted for $4 \mathrm{~h}$ at $\mathrm{pH} 5$ and $37^{\circ} \mathrm{C}$ (Table 1). All suspensions were prepared and incubated as above.

All incubation experiments were carried out twice with three separate replicates. For each sample set, a non-incubated suspension was used as a control sample. For the longincubation experiments, suspensions of autoclaved flours were also used as controls.

\section{Faba bean fermentation and bread making}

\section{Materials and micro-organisms}

The Italian faba bean flour (see "Materials and microorganisms") was used to prepare the sourdoughs and in the baking experiments. The LAB strains: Lactobacillus plantarum DPPMA B24W (B24W) (also known as VTT E-133328) from the Department of Soil, Plant and Food Science (University of Bari), L. plantarum VTT E-78076 (E76) from the culture collection of the Technical Research Centre of Finland (VTT), and Pediococcus pentosaceous I02 (I02), previously isolated from faba bean sourdough [33] and belonging to the Department of Food and Nutrition (University of Helsinki), were used in this study. The strain B24W has been used in earlier studies in different conditions to remove vicine and convicine $[13,14]$. $\beta$-glucosidase activities of the strains were screened prior their use for fermentation. Units (U) for the activity were defined as the release of $1 \mu \mathrm{mol}$ of $p$-nitrophenol from the substrate pNPG per $\mathrm{ml}$ per min and were measured as described in [23]. The obtained values presented as an average with standard deviation were $0.043 \mathrm{U} \pm 0.001 \mathrm{U}, 0.021 \mathrm{U} \pm 0.000 \mathrm{U}$, and $0.028 \mathrm{U} \pm 0.000 \mathrm{U}$ for the strains $\mathrm{B} 24 \mathrm{~W}, \mathrm{E} 76$, and $\mathrm{I} 02$, respectively.

\section{Sourdough fermentation and baking}

Before fermentation, the strains were routinely propagated in MRS broth at $30{ }^{\circ} \mathrm{C}$ (Oxoid Ltd., Basingstoke, Hampshire, UK) until the late exponential growth phase was reached (ca. $12 \mathrm{~h}$ ). Cells were harvested using centrifugation $\left(10,000 \mathrm{~g}, 10 \mathrm{~min}, 4^{\circ} \mathrm{C}\right)$, washed twice with $50 \mathrm{mmol} / 1$ of sterile potassium phosphate buffer ( $\mathrm{pH} 7.0$ ), and re-suspended in part of the tap water used to prepare the dough.

The faba bean flour and tap water were mixed in an optimal 40:60 ratio (w/v), as previously described in [30]. The LAB cells were inoculated at an initial cell density of approximately $\log 6.0 \mathrm{cfu} / \mathrm{g}$ of dough. All the doughs were fermented at 20 and $25^{\circ} \mathrm{C}$ for $24 \mathrm{~h}$ to enable acidification and production of organic acids (lactic acid, acetic acid) by LAB. The sourdoughs were prepared three times at $25^{\circ} \mathrm{C}$, once in a larger batch and twice in a smaller batch, and twice at $20^{\circ} \mathrm{C}$, and were analyzed for $\mathrm{LAB}$ growth and chemical parameters at $0 \mathrm{~h}$ and $24 \mathrm{~h}$. The presumptive lactic acid bacteria were enumerated using MRS agar medium as reported in [28]. Samples (25 g) of sourdough were taken for $\mathrm{pH}$, TTA (total titratable acidity), lactic acid, vicine and convicine, and the aglycones and were stored frozen at $-20{ }^{\circ} \mathrm{C}$ (see "Determination of acidification in sourdoughs and bread" and "Extraction of vicine, convicine and the aglycones"). The samples for vicine, convicine, and the aglycones were freeze dried (Christ Alpha 2-4 LD Plus, Osterode, Germany) prior to use. The residual moisture content of the freeze-dried samples was measured in duplicate according to AACC method 44-15A.

The fermented sourdoughs were used for wheat bread baking, as described in [30]. The mixed doughs were raised for $15 \mathrm{~min}$ at $30{ }^{\circ} \mathrm{C}$. Then, they were molded and again raised for $45 \mathrm{~min}$ at $30{ }^{\circ} \mathrm{C}$. Baking was carried out at $200{ }^{\circ} \mathrm{C}$ for $15 \mathrm{~min}$. In total, four breads were obtained, each containing a 30:70 ratio of faba bean flour to wheat flour and a 60:40 ratio of total flour to water. The control doughs (NF) contained non-fermented faba bean and were prepared under the same conditions as above. Samples (25 g) of fermented doughs and NF control doughs and slices $(25 \mathrm{~g})$ of their corresponding breads were used for $\mathrm{pH}$, TTA and vicine, convicine, and aglycone analysis and were stored frozen at $-20^{\circ} \mathrm{C}$ (see "Determination of acidification in sourdoughs and bread" and "Extraction of vicine, convicine and the aglycones"). A subset of samples (for vicine, convicine, and the aglycones) were freeze dried prior to use. All baking experiments were conducted once for sourdoughs (from larger batch) from $25^{\circ} \mathrm{C}$ and twice from those prepared at $20{ }^{\circ} \mathrm{C}$. 


\section{Determination of acidification in sourdoughs and bread}

First, the frozen samples of the sourdoughs and breads that were measured for acidity were thawed for $30 \mathrm{~min}$ at room temperature. To measure $\mathrm{pH}$ and TTA, $10 \mathrm{~g}$ of sourdough was suspended in $90 \mathrm{ml}$ of Milli-Q water by mixing for 1 min with a hand blender (Bamix M122, Mettlen, Switzerland). Correspondingly, $10 \mathrm{~g}$ of bread was first mixed with $5 \mathrm{ml}$ of acetone and then suspended in $100 \mathrm{ml}$ of Milli-Q water. The measurements were conducted in duplicate using Mettler Toledo EasyPlus Titration with pH-meter (Mettler Toledo, DGi115-SC), which gave the initial $\mathrm{pH}$ value, and then the samples were titrated to $\mathrm{pH} 8.5$ using $1 \mathrm{~N} \mathrm{NaOH}$.

Lactic acid content was measured in duplicate in sourdough samples that had been fermented at $20{ }^{\circ} \mathrm{C}$ using an HPLC-UV method [34]. One gram of sourdough was mixed with $1 \mathrm{ml}$ of $5 \mathrm{mM} \mathrm{H}_{2} \mathrm{SO}_{4}$ solution. The mixture was centrifuged for $10 \mathrm{~min}$ at $10,000 \mathrm{~g}$ with Sigma 1-14 K (Sigma Laborzentrifugen $\mathrm{GmbH}$, Germany) at $4{ }^{\circ} \mathrm{C}$, and the supernatant was taken and diluted to $1: 25$. The solution was filtrated and injected into the HPLC system. The column was an Agilent Hi-Plex H $(7.7 \times 300 \mathrm{~mm})$ with a particle size of $8 \mu \mathrm{m}$ (Agilent Technologies, Santa Clara, CA, USA). The column was used at $50{ }^{\circ} \mathrm{C}$. The eluent was a $5 \mathrm{mM} \mathrm{H}_{2} \mathrm{SO}_{4}$ solution that had a flow rate of $0.4 \mathrm{ml} / \mathrm{min}$. Detection was conducted at $210 \mathrm{~nm}$. From the sourdoughs fermented at $25^{\circ} \mathrm{C}$, lactic acid was measured in duplicate using a lactic acid kit (Megazyme, Ireland). First, $1 \mathrm{~g}$ of sourdough was mixed with $1 \mathrm{ml}$ of Milli-Q water and centrifuged as described above. Then, $1 \mathrm{ml}$ of supernatant was deproteinized using Carrez reagents and diluted 1:50-1:100 to the final volume prior to use.

\section{Extraction of vicine, convicine and the aglycones}

The sample preparation of the suspensions after incubation for vicine and convicine analysis was begun by adding $1 \mathrm{ml}$ $(8000 \mu \mathrm{g} / \mathrm{ml})$ of internal standard uridine ( $\geq 99 \%$, SigmaAldrich, USA) and $15 \mathrm{ml}$ of Milli-Q water and mixing for 1 min with a Vortex. Then, to deproteinize the solutions, $2.5 \mathrm{ml}$ of strong perchloric acid was added. After mixing, the supernatant was separated from the flour particles by centrifuging with Hermle Z323 (Hermle LaborTechnik $\mathrm{GmbH}$, Germany) for $10 \mathrm{~min}$ at $10,000 \mathrm{~g}$. The supernatant was collected and its volume set to $25 \mathrm{ml}$. The filtered solutions were injected into the HPLC (see "HPLC-UV analysis of vicine, convicine and the aglycones"). Deproteinization was not conducted for the samples that were incubated at $\mathrm{pH} 1$ and 2. All analyses were carried out in three replicates.

The dried sourdough and bread samples for vicine and convicine analysis were ground (Grindomix GM 200, Retsch $\mathrm{GmbH}$, Haan, Germany) at $8000 \mathrm{rpm}$ for $30 \mathrm{~s}$ and extracted similarly as in [35]. Samples of $0.4-0.5 \mathrm{~g}$ were extracted three times with $5 \mathrm{ml}$ of perchloric acid (7\%) after addition of $1 \mathrm{ml}$ of uridine $(4000 \mu \mathrm{g} / \mathrm{ml})$. The volume was set to $25 \mathrm{ml}$, and then the samples were filtered and injected into the HPLC (see "HPLC-UV analysis of vicine, convicine and the aglycones"). Three analytical replicates were performed.

The aglycones were extracted from selected samples (fermentations with I02 and B24W) of the freeze-dried sourdoughs, the final doughs that contained $30 \%$ faba bean flour, and the corresponding breads that had been stored at $-20{ }^{\circ} \mathrm{C}$. The NF control doughs and breads were also analyzed. The extraction followed the same procedure as in [12]. The freeze-dried samples $(0.1-0.3 \mathrm{~g})$ were weighed in a Falcon tube, and then $10 \mathrm{ml}$ of Milli-Q water was added. After mixing for $2 \mathrm{~min}$, the suspensions were transferred to Amicon Ultra 0.5-ml filters (Millipore, Billerica, MA) and centrifuged with Sigma $1-14 \mathrm{~K}$ for $5 \mathrm{~min}$ at $10,000 \mathrm{~g}$ and $8^{\circ} \mathrm{C}$. Then, the supernatants were transferred into HPLC vials and analyzed directly (see "HPLC-UV analysis of vicine, convicine and the aglycones"). In addition, to evaluate stability of the aglycones, the suspended samples were re-analyzed after they had stood in test tubes at room temperature for $0.5,2$, and $20 \mathrm{~h}$. All analyses were conducted in duplicate.

\section{HPLC-UV analysis of vicine, convicine and the aglycones}

The reversed-phase HPLC-UV method used to analyze vicine, convicine, and the aglycones was based on earlier work [12, 35]. An Agilent 1200 instrument (Agilent Technologies, Santa Clara, CA, USA) was equipped with a degasser unit (G1379B), a binary pump (G1312A), a Hip-ALS autosampler (G1367B), a thermostatted column compartment (G1316A), and a diode array detector (G1315B). Separation was conducted using an Atlantis T3 column $(4.6 \times 100 \mathrm{~mm}, 3 \mu \mathrm{m}, \mathrm{C} 18$ phase) (Waters, Milford, USA) attached to an Atlantis T3 guard column $(4.6 \times 20 \mathrm{~mm})$. The compounds were separated using Milli-Q water containing $0.1 \%$ of formic acid as an eluent at a flow rate of $0.8 \mathrm{ml} /$ min. The column temperature was $30{ }^{\circ} \mathrm{C}$, and the column was washed with $70 \%$ acetonitrile in gradient run. The injection volume was 10-20 $\mu$ l. The compounds were detected at $273 \mathrm{~nm}$, and the peak areas were recorded as $\mathrm{mAu} \times \mathrm{sec}$ using Agilent 1200 online software. The vicine, convicine, and aglycones were identified according to their retention times and the UV spectra observed earlier in $[12,35]$.

The vicine standard ( $\geq 98 \%$, Cfm Oskar Tropitzsch $\mathrm{GmbH}$, Germany) was used for quantification against internal standard uridine. The standard solutions of vicine ranged from 0.15 to $3 \mu \mathrm{g}$ in injection and had a constant level of uridine ( $3 \mu \mathrm{g}$ in injection) in $7 \%$ perchloric acid. Convicine was also quantified from the standard curve of vicine. Flour from the Kontu (2011) cultivar was used as an inhouse reference sample to monitor the levels. The vicine 
and convicine concentrations $(n=20)$ were $5.64 \pm 0.07 \mathrm{mg} / \mathrm{g}$ (CV \% 3.6) and $3.70 \pm 0.20 \mathrm{mg} / \mathrm{g}(\mathrm{CV} \%$ 6.5) per fresh weight, respectively.

The losses of vicine and convicine were evaluated by comparing the incubated suspensions to non-incubated ones, and the fermented samples to the starting point of fermentation $(0 \mathrm{~h})$. In baking, fermented breads were compared to control NF bread. Loss was calculated as a percentage value.

\section{Data analyses}

Statistical differences between the losses of vicine and convicine in incubated suspensions were evaluated using oneway ANOVA and Least Significant Difference (LSD) (SPSS version 22.0, IBM SPSS Statistics, Chicago, IL, USA). Differences were considered statistically significant at $p<0.05$.

\section{Results and discussion}

\section{Effect of incubation on vicine and convicine contents in suspensions}

The losses of vicine and convicine were rather low during the short incubations of faba bean flours, indicating low activity of the endogenous $\beta$-glucosidase for these substrates (Fig. 1a). Overall, $87-94 \%$ of vicine and $89-95 \%$ of convicine was left in the suspensions of Kontu flour after incubation for $4 \mathrm{~h}$ at the $\mathrm{pH}$ values and temperatures tested. In suspensions of the Italian flour, $87-98 \%$ and $91-100 \%$ of vicine and convicine, respectively, were left. The losses were slightly higher at the lower $\mathrm{pH}$ values of 4.5 and 5 than at $\mathrm{pH}$ 6.5. Previously, vicine and convicine from faba bean paste were shown to be hydrolyzed by $\beta$-glucosidase from almonds more effectively at low $\mathrm{pH}$ values (3.5-4.5) than at $\mathrm{pH} 6$ [10]. In that study, decreasing the $\mathrm{pH}$ using lemon juice was crucial to activating the $\beta$-glucosidase. In the present study, due to minor differences in the losses at $30^{\circ} \mathrm{C}$ and $37{ }^{\circ} \mathrm{C}$, all longer incubations and those in the cultivar comparison experiments were carried out at $37^{\circ} \mathrm{C}$.

When incubation time was prolonged to $24 \mathrm{~h}$, somewhat higher losses were found (Fig. 1b). After incubation at $\mathrm{pH}$ values of 4.5 and $5,74-81 \%$ of vicine and $75-79 \%$ of convicine were left in the Kontu and Italian flour suspensions, respectively. The differences in the results caused by the two $\mathrm{pH}$ values were not statistically significant $(p<0.05)$. In the suspensions made from autoclaved flours, no vicine and convicine were lost during the $24 \mathrm{~h}$ incubation at $\mathrm{pH}$ 5 . The heat treatment inactivated the endogenous enzymes and microbes, both of which may have contributed to the losses observed during the long incubation periods. Vicine was also quite stable at $\mathrm{pH} 1$ and $2 ; 90-92 \%$ of vicine remained at both these $\mathrm{pH}$ values. In contrast, convicine was less stable in these acidic conditions. In the suspensions of both flours, $82-84 \%$ of convicine was left at $\mathrm{pH}$ 2 and only $33-34 \%$ at pH 1 (Fig. 1b). This result is in line with previous findings, in which convicine was more unstable than vicine was in acidic conditions [36].

The losses of vicine and convicine did not differ significantly in the suspensions of the selected faba bean cultivars. When incubated for $4 \mathrm{~h}$ at $\mathrm{pH} 5$ and $37{ }^{\circ} \mathrm{C}, 89-95 \%$ of vicine and $86-96 \%$ of convicine remained in the four cultivars studied from the 2 years (Fig. 1c). The losses of vicine and convicine were statistically similar $(p<0.05)$ for all cultivars and years, apart from two cultivars from 2015: Alexia and Kontu. The Alexia cultivar showed a slightly higher loss of vicine than the other cultivars and, in the Kontu cultivar, slightly more vicine was left compared to the other cultivars. This result showed that there was no notable variation in activities among cultivars that were comparably grown in the same conditions. All the cultivars used in this study contained high amounts of vicine and convicine. However, new germplasms with low vicine and convicine contents, e.g., Melodié, are developed and will become more common. These sources may not need processing to remove vicine and convicine prior consumption [37].

The role of $\beta$-glucosidases in faba bean is poorly understood and its activity has been measured in only a few studies. $\beta$-glucosidase activity was discussed in a review by Arese and De Flora [22], which reported the highest activity in mature seeds. However, no information is available on the substrate used in the activity test. $\beta$-glucosidase activity was also found in faba bean flours using the artificial pNPG-substrate [13], indicating endogenous enzyme activity.

The present incubation experiments showed that some loss occurred during conditions optimal for enzymatic activity, but in practice, the hydrolysis was insufficient to significantly reduce the amounts of vicine and convicine. Under optimal conditions, enzymes are activated in a short time and, therefore, the present study initially used relatively short incubation times for suspensions and prolonged them in later experiments. In addition to hydrolysis by endogenous enzymes, a contribution of spontaneous fermentation was possible, especially during long incubations, as discussed earlier. The conditions were initially kept natural and microbial growth was not inhibited. Some hydrolysis of vicine and convicine has occurred in spontaneous fermentations [13, 14]. However, this hydrolysis was quite small and occurred in long incubations ( $48 \mathrm{~h}$, $\left.30{ }^{\circ} \mathrm{C}\right)$.

Consequently, an external enzyme source is needed to eliminate vicine and convicine. Therefore, $\beta$-glucosidase should be either added as enzyme preparates or produced by microbes, including LAB, during controlled fermentation. 
Fig. 1 Losses of vicine and convicine in two faba bean flours (Kontu and Italian) in a short incubation $(4 \mathrm{~h})$ at $\mathrm{pH}$ range $4.5-6.5$ and $30^{\circ} \mathrm{C}$ and at $\mathrm{pH} 5$ and $37^{\circ} \mathrm{C}$; b long incubation $(24 \mathrm{~h})$ at $\mathrm{pH}$ values 4.5 and 5 and at low pH (1 and 2) and for autoclaved flours at $\mathrm{pH} 5$ and $37{ }^{\circ} \mathrm{C}$; $\mathbf{c}$ at $\mathrm{pH} 5$ and $37^{\circ} \mathrm{C}$ in cultivar comparison (Alexia, CDC Fatima, Kontu, CDC

SSNS-1) from 2 years (2011,

2015). The remaining percentage value (\%) is calculated by comparing the vicine and convicine contents to those in the non-incubated controls. The incubation was repeated twice with three individual replicates. The results were calculated per dry weight. Bars marked by different letters $(A>C, a>c)$ are significantly different by the LSD test $(P<0.05, n=6)$

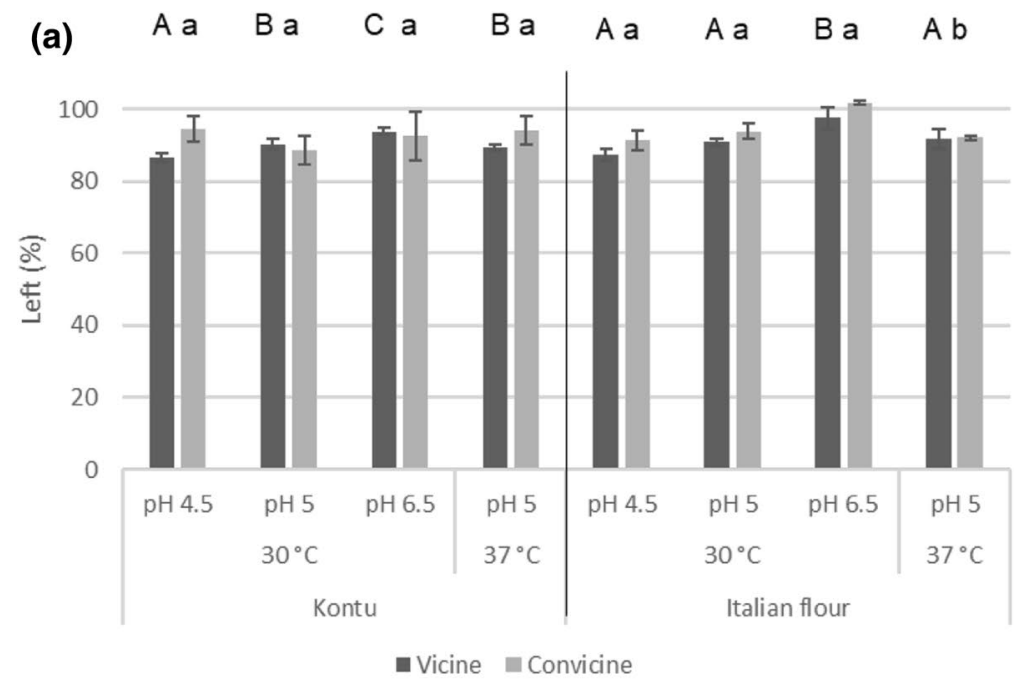

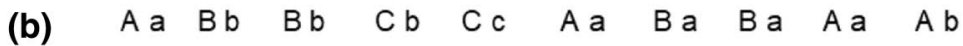

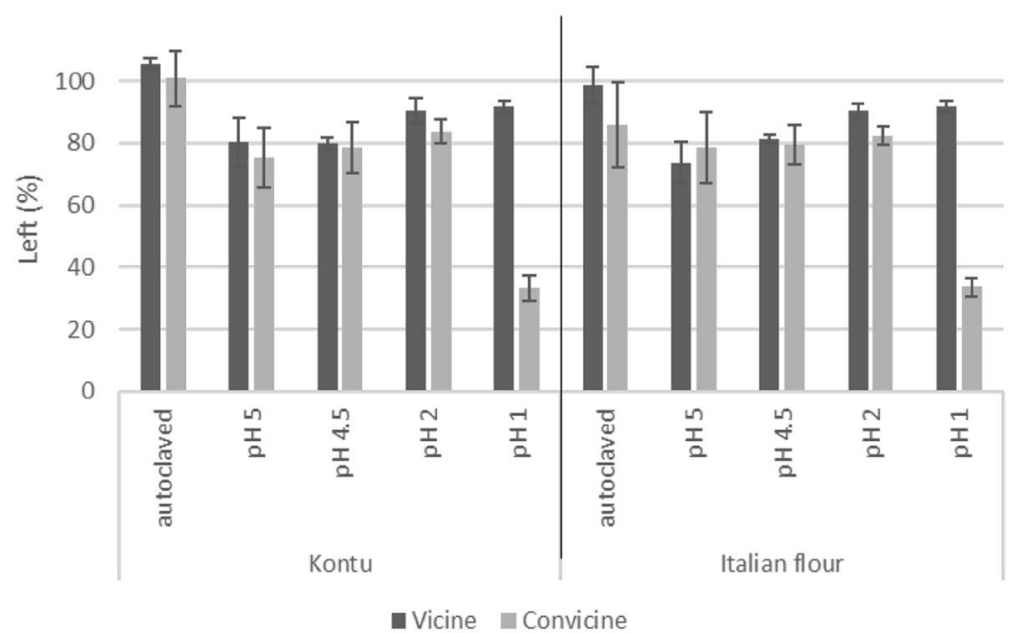

(c) $\quad A$ a $A B$ a $B$ a $A B$ a $A B$ a $A B$ a $A B$ a $A B$ a

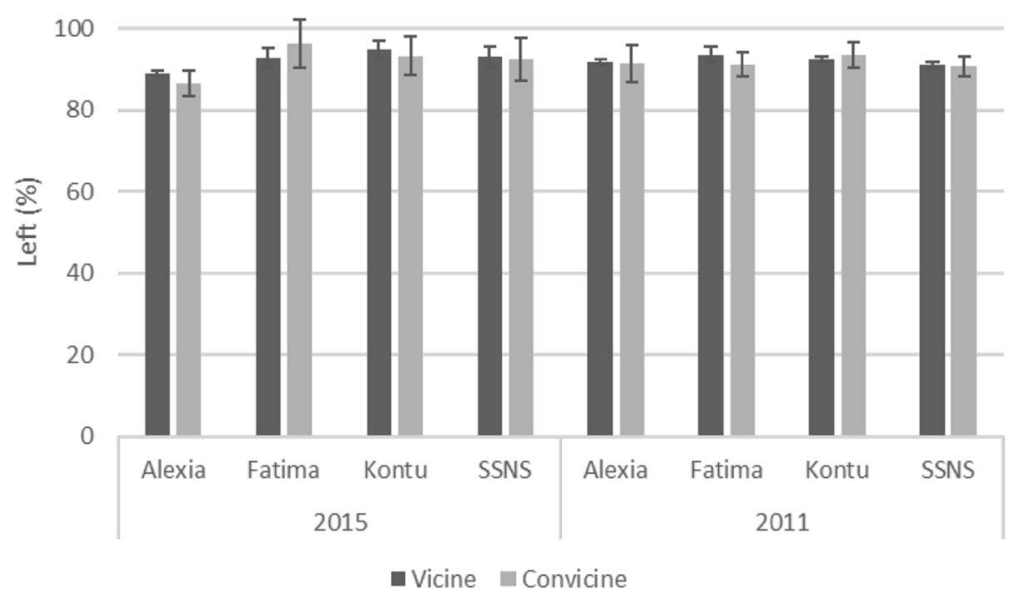




\section{Effect of fermentation and baking on vicine and convicine contents}

The present study surveyed the possibility of removing vicine and convicine by fermentation using $\mathrm{LAB}$ possessing $\beta$-glucosidase. Italian faba bean flour was fermented with three LAB strains at two temperatures to induce more intensive breakdown of vicine and convicine than in the suspensions but under conditions mild enough to achieve acceptable sensory properties.

During fermentation at $20{ }^{\circ} \mathrm{C}$, the cell density increase of the presumptive LAB was of 2.5-3 log cycles and reached values of 8.95-9.00 log cfu/g of dough (Table 2). The $\mathrm{pH}$ value for the sourdoughs was 5.3-5.4, while the TTA and lactic acid ranges were $8.5-10.0 \mathrm{ml}$ of $\mathrm{NaOH} 1 \mathrm{~N}$ and $0.41-0.51 \mathrm{~g} / 100 \mathrm{~g}$, respectively. When the strains I02 and B24W were fermented at $25^{\circ} \mathrm{C}$, the growth rate $(\Delta \log )$ was similar to that at $20^{\circ} \mathrm{C}$. Sourdough fermented by the strain E76 showed a slight increase $(\Delta \log 3.15)$ and a final cell density of $9.65 \mathrm{log} \mathrm{cfu} / \mathrm{g}$. In both conditions tested, the differences in growth and acidification among the strains were small, although at $25{ }^{\circ} \mathrm{C}$, changes in cell density and $\mathrm{pH}$ were higher for the strain E76 than for the strains I02 and B24W. As expected, fermentation at $25{ }^{\circ} \mathrm{C}$ led to higher acidity. The $\mathrm{pH}$ ranged from 4.4 to 4.8 , the TTA from 13.0 to $14.9 \mathrm{ml}$ of $\mathrm{NaOH} 1 \mathrm{~N}$, and the lactic acid from 0.91 to $1.32 \mathrm{~g} / 100 \mathrm{~g}$.

The fermentation conditions significantly affected the loss of vicine and convicine. At a lower fermentation temperature $\left(20^{\circ} \mathrm{C}\right)$, losses did not occur, apart from a slight reduction in sourdough fermented by the strain I02. At a higher temperature $\left(25^{\circ} \mathrm{C}\right)$, strains $\mathrm{I} 02$ and B24W, in particular, were able to hydrolyze both vicine and convicine. In sourdoughs fermented at $25{ }^{\circ} \mathrm{C}$ for $24 \mathrm{~h}$ by the strains I02, E76, and $\mathrm{B} 24 \mathrm{~W}$, the proportions of vicine remaining were in larger batch $56 \%, 90 \%$ and $72 \%$ and in smaller batch $15 \%, 76 \%$ and $18 \%$, respectively. Those of convicine were $78 \%, 87 \%$ and $80 \%$ in larger batch, and in smaller batch $53 \%, 86 \%$ and $66 \%$, respectively (Fig. 2a). Vicine levels were lowered in general more than convicine levels. A variation in hydrolysis efficiency was noted, even though no biological differences were observed among the replicates. Consequently, the variation may have resulted from the sampling, for example, the handling of the large sample volumes.

The $\beta$-glucosidase activity of the selected starters toward pNPG was in line with the hydrolysis levels of vicine and convicine (Fig. 2a). Among the starters, L. plantarum B24W showed the highest $\beta$-glucosidase activity, followed by $P$. pentosaceus I02. Therefore, the lowest losses of vicine and convicine, found in sourdough inoculated with $L$. plantarum E76, were probably due to its lowest $\beta$-glucosidase activity. Nevertheless, $\beta$-glucosidase activity was likely the reason for the losses of vicine and convicine, because vicine was stable, even at $\mathrm{pH} 1$, and the acidity itself did not cause losses during the incubation of the autoclaved flours.

Lactobacillus plantarum B24W, originally isolated from cheese, has shown efficiency in hydrolyzing $\beta$-glycosides, i.e., isoflavones in soy milk and vicine and convicine in longer fermentation of faba bean [14, 23]. In previous studies, this strain has adapted relatively slowly in faba bean matrix, but nevertheless has shown good growth performance [14]. P. pentosaceus $\mathrm{I} 02$ was recently isolated from faba bean flour sourdough [33], while L. plantarum E76 was isolated from Finnish rye sourdoughs and used to ferment wheat flour [38, 39]. Despite the different origins of the strains, all grew efficiently in faba bean.
Table 2 Properties of sourdoughs (fermented for $24 \mathrm{~h}$ ) and their corresponding breads

\begin{tabular}{lllllllll}
\hline & $\left({ }^{\circ} \mathrm{C}\right)$ & Strain & $\begin{array}{l}\text { Cell density } \\
(\text { log cfu/g) }\end{array}$ & $\Delta \log$ & PH & $\Delta \mathrm{pH}$ & \multicolumn{1}{l}{$\begin{array}{l}\text { TTA } \\
(\mathrm{ml})\end{array}$} & \multicolumn{1}{l}{$\begin{array}{l}\text { Lactic acid } \\
(\mathrm{g} / 100 \mathrm{~g} \text { dough })\end{array}$} \\
\hline Sourdough & 20 & I02 & $9.00 \pm 0.07$ & 3.05 & $5.3 \pm 0.2$ & 0.86 & $8.6 \pm 0.4$ & $0.51 \pm 0.04$ \\
& & E76 & $8.90 \pm 0.40$ & 2.51 & $5.4 \pm 0.4$ & 0.82 & $10.0 \pm 2.7$ & $0.48 \pm 0.22$ \\
& & B24W & $8.95 \pm 0.20$ & 2.45 & $5.3 \pm 0.5$ & 0.93 & $8.5 \pm 0.8$ & $0.41 \pm 0.06$ \\
& 25 & I02 & $9.25 \pm 0.07$ & 3.00 & $4.7 \pm 0.0$ & 1.74 & $13.8 \pm 1.20$ & $0.99 \pm 0.18$ \\
& & E76 & $9.65 \pm 0.07$ & 3.15 & $4.4 \pm 0.1$ & 1.91 & $14.9 \pm 1.90$ & $1.32 \pm 0.26$ \\
Bread & & B24W & $9.10 \pm 0.20$ & 2.56 & $4.8 \pm 0.2$ & 1.64 & $13.0 \pm 0.10$ & $0.91 \pm 0.10$ \\
& & NF & & & $5.9 \pm 0.0$ & & $4.3 \pm 0.2$ & \\
& I02 & & & $5.2 \pm 0.0$ & & $6.7 \pm 0.0$ & \\
& & & & $5.0 \pm 0.0$ & & $7.8 \pm 0.3$ & \\
& E76 & & & $5.3 \pm 0.0$ & & $6.7 \pm 0.0$ & \\
& B24W & & & $4.9 \pm 0.0$ & & $7.4 \pm 0.1$ & \\
& I02 & & & $4.7 \pm 0.0$ & & $8.6 \pm 0.0$ & \\
& E76 & & & $4.9 \pm 0.0$ & & $7.6 \pm 0.0$ & \\
\hline
\end{tabular}

$N F$ bread containing non-fermented faba bean

Measurements were made per fresh weight and conducted in duplicate from each process replicate 
Fig. 2 Losses of vicine and convicine in a sourdoughs and b breads. Fermentation was conducted at $20^{\circ} \mathrm{C}$ and $25^{\circ} \mathrm{C}$ for $24 \mathrm{~h}$ with three strains (I02, E76, and B24W). The breads contained $30 \%$ faba bean flour from the total weight of flours. The results were calculated per dry weight. The remaining percentage value $(\%)$ is calculated by comparing faba bean sourdoughs and sourdough breads with doughs in the starting point and breads made with non-fermented faba flour. There were two replicates of the experiments conducted at $20{ }^{\circ} \mathrm{C}$, for both fermentation and baking. At $25^{\circ} \mathrm{C}$, only replicate * was used in baking, but fermentation was conducted three times. There were three analytical replicates
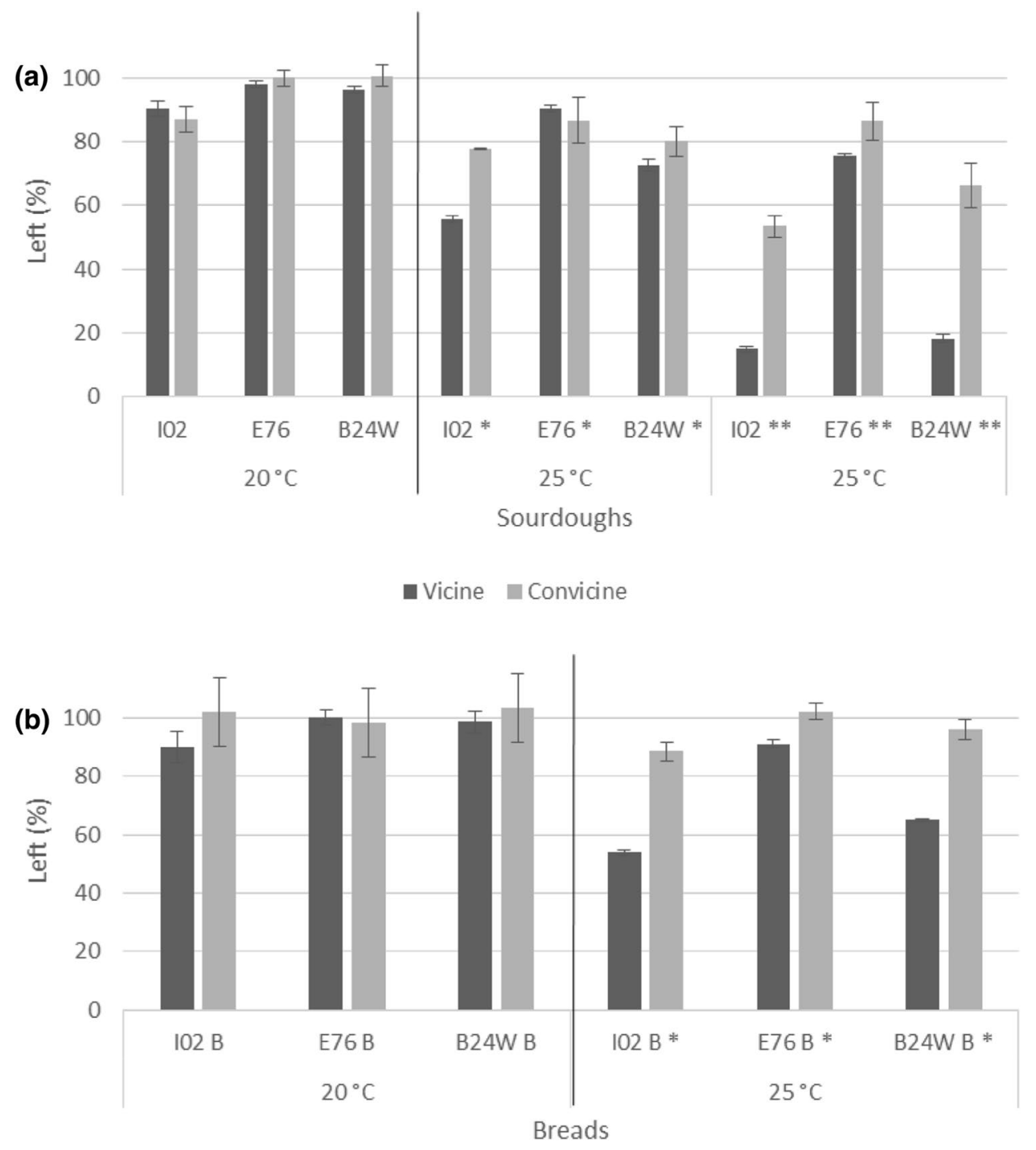

- Vicine Convicine
All three strains used in the present study showed activity with the synthetic pNPG substrate and further activity in hydrolyzing vicine and convicine in real fermentation conditions. However, hydrolysis required a higher fermentation temperature $\left(25^{\circ} \mathrm{C}\right)$, because at a low fermentation temperature $\left(20^{\circ} \mathrm{C}\right)$ vicine and convicine were not reduced. The present study conducted fermentation for $24 \mathrm{~h}$, which was a shorter time than that used in earlier studies [13, 14]. The results showed that when acidification is controlled, marked removal of vicine and convicine may be challenging. In previous experiments, the losses of vicine and convicine were more pronounced when more intense fermentation was used, with more than $90 \%$ of vicine and convicine disappearing in $48 \mathrm{~h}$ at $30{ }^{\circ} \mathrm{C}$ when fermented with the strain B24W [14]. Glucosidase activities in LAB are tightly linked to the carbohydrate metabolism, and their mechanisms depend on multiple factors [28], including the specific adaptation to the environment (growth, acidification, or activation of specific metabolic pathways of a defined strain). More information is needed on the metabolic performance of $\beta$-glucosidase active strains to direct their use for the most efficient transformation of faba bean.

In the present study, the breads contained $30 \%$ of either fermented or NF faba bean. In the NF bread, the $\mathrm{pH}$ was 5.9 and the TTA was $4.3 \mathrm{ml}$ of $\mathrm{NaOH} 1 \mathrm{~N}$ (Table 2). When sourdough that had been fermented at $20^{\circ} \mathrm{C}$ was added, the $\mathrm{pH}$ values were 5.0-5.3 and the TTA values were $6.7-7.8 \mathrm{ml}$ of $\mathrm{NaOH} 1 \mathrm{~N}$. The higher acidity of the sourdough fermented at $25^{\circ} \mathrm{C}$ reflected on the corresponding breads, showing $\mathrm{pH}$ 4.7-4.9 and TTA of 7.4-8.6 ml of $\mathrm{NaOH} 1 \mathrm{~N}$, respectively.

When the vicine and convicine levels in sourdough breads were compared with those in NF bread (Fig. 2b), the 
differences were comparable to the losses in the fermentation step (Fig. 2a). Thus, the stability of the vicine and convicine in the later steps of the baking process did not differ for sourdough bread and NF bread. To further evaluate the losses in the baking process, the amounts of vicine and convicine in faba bean doughs and breads were compared, taking into account the proportion of faba bean sourdough in the breads. This comparison showed that the losses during the entire baking process were $11-25 \%$ and $11-42 \%$ for vicine and convicine, respectively.

The hydrolysis of vicine and convicine could have occurred during the bread making process due to the $\beta$-glucosidase produced by either the LAB or the baker's yeast, which is also known to have $\beta$-glucosidase activity $[40,41]$. Increased activity of $\beta$-glucosidase due to baker's yeast has been noted in soy-wheat dough fermented for $2 \mathrm{~h}$ at $22-48{ }^{\circ} \mathrm{C}$ [40]. Nevertheless, in the present study, the time for hydrolysis (dough raising 15 and $45 \mathrm{~min}$ at $30{ }^{\circ} \mathrm{C}$ ) was relatively short and the estimated losses during baking at $200{ }^{\circ} \mathrm{C}$ for $15 \mathrm{~min}$ were small, especially for vicine. The baking process was not expected to cause notable losses of vicine and convicine, because they are relatively heat stable $[8,10]$.

\section{Aglycones formed from hydrolysis}

When using a fermentation temperature of $25^{\circ} \mathrm{C}$, hydrolysis products of vicine and convicine, divicine and isouramil were detected in freeze-dried sourdoughs that had been inoculated with strains of I02 (Fig. 3) and B24W (data for I02 in Fig. 3). The retention times and UV spectra of the aglycones were consistent with those in earlier studies [12, 15]. In contrast, these aglycones were not detected in doughs fermented at a lower temperature, $20{ }^{\circ} \mathrm{C}$ (data not shown), or in either the NF control doughs or breads.

Figure 3 a shows how the amounts of vicine and convicine decreased and the aglycones appeared during the sourdough process. In dough, added wheat flour diluted the contents (Fig. 3b). The content of divicine was $18 \%$ in dough from the amount that was in sourdough, and the corresponding proportion of isouramil was $12 \%$. Finally, the aglycones were not detected at all in the breads (Fig. 3c) in contrast to the corresponding doughs (Fig. 3b). These experiments provided preliminary data about the aglycones in bread processing. The results indicated that when heat-treatment in bread baking inactivated the enzymes and stopped the hydrolysis of vicine and convicine, the aglycones that had formed earlier were degraded and gradually disappeared.

To study stability of the aglycones in suspended freezedried sourdoughs, they were kept at room temperature for $0.5,2$, and $20 \mathrm{~h}$ (Fig. 4). At $0.5 \mathrm{~h}$, a marked decrease in divicine and isouramil levels occurred. This decrease continued at $2 \mathrm{~h}$, and at $20 \mathrm{~h}$, the aglycones were undetectable, thus indicating that they were not stable in the suspensions. In previous studies, the aglycones disappeared in suspensions treated with added $\beta$-glucosidase under $\mathrm{pH}$ and temperature conditions relevant to the food system [12], and the same happened in sourdoughs and doughs, indicating that stabilizing factors do not occur in faba bean matrix.

In addition to the disappearance of the aglycones, there were indications of the formation of oxidized divicine before the total loss of the UV-absorbing compounds. Our previous study found that a peak, suggested to be oxidized divicine, was formed during the hydrolysis of vicine [12]. In the present study, the peak was also formed, and its amount increased 1.3 -fold at $0.5 \mathrm{~h}$ in suspension, while divicine decreased (Fig. 4). The aglycone degradation products were unstable, as shown by the loss of UV absorbance in a few hours, which has also been shown in previous studies [12, 15].

These results were also in line with those of previous studies on faba bean paste [10] and sourdoughs [13], in which the aglycones seemed to degrade and disappear. To our knowledge, the present study is the first in which the aglycones of vicine and convicine were studied in real food matrices.

\section{Conclusions}

This study investigated the possibility of removing vicine and convicine from faba bean using endogenous or microbiologically produced $\beta$-glucosidase activity. The need for external sources of the enzyme was confirmed, because the activity of endogenous $\beta$-glucosidase was too low to have any practical effect on removing vicine and convicine. Likewise, acidity itself did not cause vicine losses. Instead, LAB fermentation with $\beta$-glucosidase positive strains induced the hydrolysis of vicine and convicine. However, removal efficiency was dependent on the strain and the fermentation temperature. Mild fermentation conditions did not lead to significant reduction in the amounts of vicine and convicine. Further screening of $\beta$-glucosidase active LAB strains and deeper understanding of their performance during faba bean fermentation are necessary to enable elimination of vicine and convicine while also maintaining acceptable sensory properties. Vicine and convicine were found in breads as well, thus indicating that baking under slightly acidic conditions did not degrade them. The aglycones of vicine and convicine were detectable before baking but not in the final bread product. Fermentation of faba bean or addition of food-grade $\beta$-glucosidase enzyme can be considered as a tool for removal of vicine and convicine, although optimization of processing conditions is required. 

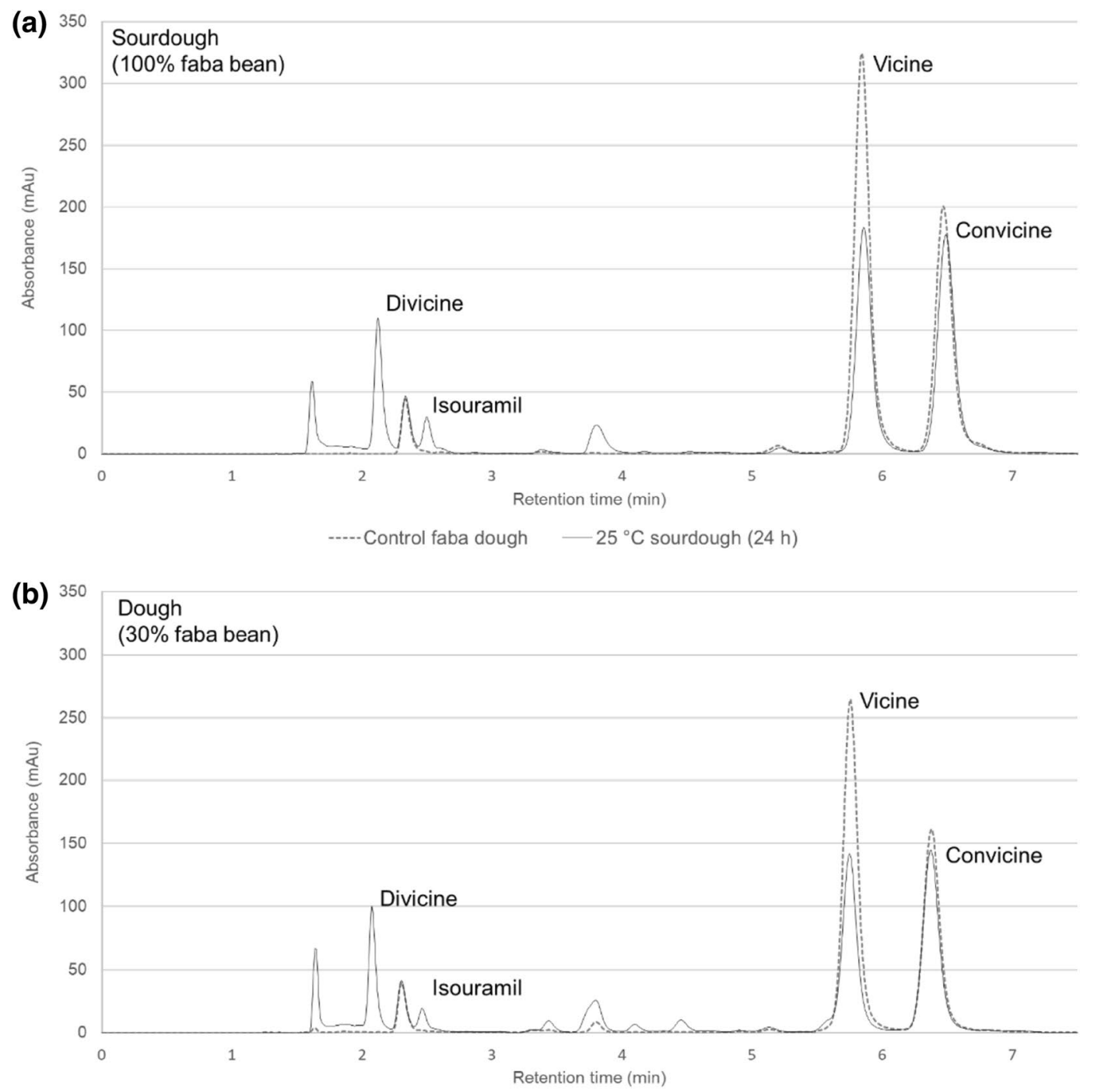

----Control dough —Dough with $25^{\circ} \mathrm{C}$ sourdough

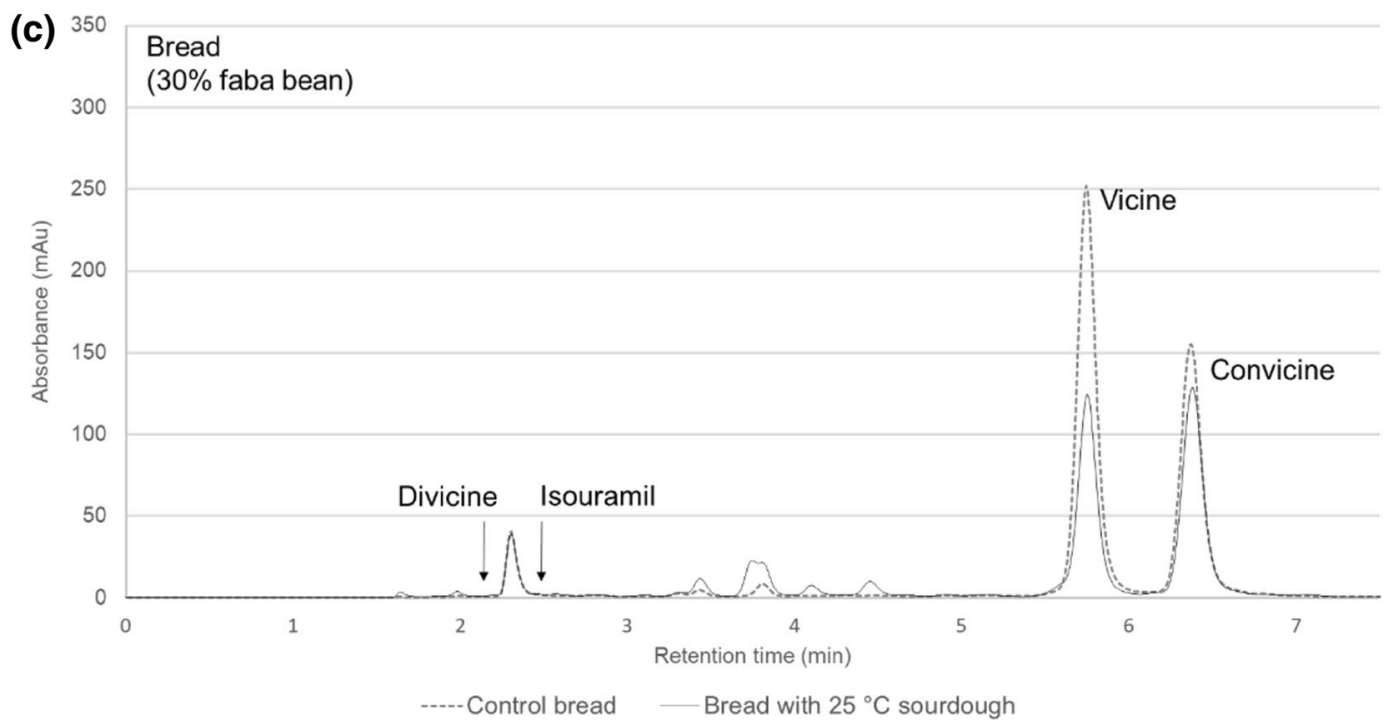


4Fig. 3 Chromatograms from suspensions of a freeze-dried sourdough ( $100 \%$ faba bean, inoculated with strain I02) fermented for $24 \mathrm{~h}$ at $25{ }^{\circ} \mathrm{C}$; b dough ( $30 \%$ faba bean); and $\mathbf{c}$ bread (30\% faba bean) showing appearance and disappearance of the aglycone forms of vicine and convicine. The injection volume was $20 \mu \mathrm{l}$. The measurements were made in duplicate. Fermented suspensions are marked with black lines and controls are marked with grey dotted lines

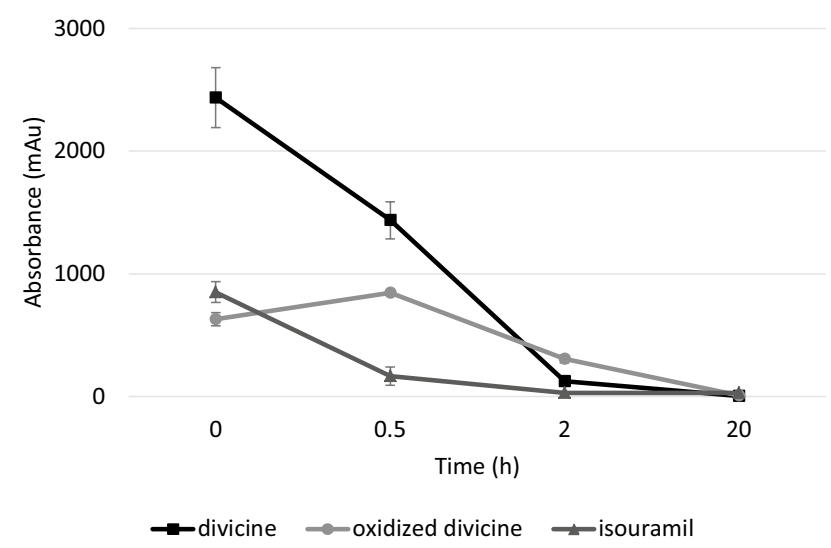

Fig. 4 Stability of the aglycones and further product in suspensions of freeze-dried sourdough. Faba bean dough inoculated with the strain I02 was fermented at $25{ }^{\circ} \mathrm{C}$ for $24 \mathrm{~h}$. The error bars indicate the difference between two replicates

Acknowledgements Open access funding provided by University of Helsinki including Helsinki University Central Hospital. This work was carried out under the European Project "BIOPROT" (FP7-ERA-NetSUSFOOD), with a grant from The Doctoral Program in Food Chain and Health of the University of Helsinki. The authors would like to thank Miikka Olin for valuable technical help and Docent Frederick Stoddard and Dr. Clara Lizarazo for providing the faba beans. We also gratefully acknowledge funding from the Finnish Cultural Foundation.

\section{Compliance with ethical standards}

Conflict of interest The authors declare that they have no conflict of interest.

Compliance with ethics requirements This article does not contain any studies with human or animal subjects.

Open Access This article is distributed under the terms of the Creative Commons Attribution 4.0 International License (http://creativeco mmons.org/licenses/by/4.0/), which permits unrestricted use, distribution, and reproduction in any medium, provided you give appropriate credit to the original author(s) and the source, provide a link to the Creative Commons license, and indicate if changes were made.

\section{References}

1. Watson CA, Reckling M, Preissel S, Bachinger J, Bergkvist G, Kuhlman T, Lindström K, Nemecek T, Topp CFE, Vanhatalo A, Xander P, Murphy-Bokern D, Stoddard F (2017) Adv Agron 144:235-303
2. Day L (2013) Trends Food Sci Technol 32:25-42

3. Jacob C, Carrasco B, Schwember AR (2016) Plant Cell Tissue Organ Culture 127:561-584

4. Ray H, Georges F (2010) GM crops 1(2):99-106

5. Arese P, Gallo V, Pantaleo A, Turrini F (2012) Transfus Med Hemother 39:328-334

6. Cappelini MD, Fiorelli G (2008) Lancet 371:64-74

7. Baker MA, Bosia A, Pescarmona G, Turrini F, Arese P (1984) Toxicol Pathol 12:331-336

8. Cardaror-Martinez A, Maya-Ocana K, Ortiz-Moreno A, HerreraCabrera BE, Davila-Ortiz G, Muzquiz M (2012) J Food Qual 35:419-428

9. Patterson CA, Curran J, Der T (2017) Cereal Chem 94:2-10

10. Arbid MSS, Marquardt RR (1985) J Sci Food Agric 36:839-846

11. McKay AM (1992) J Appl Bacteriol 72:475-478

12. Pulkkinen M, Zhou X, Lampi A, Piironen V (2016) Food Chem 212:10-19

13. Rizzello CG, Losito I, Facchini L, Katina K, Palmisano F, Gobbetti M, Coda R (2016) Sci Rep 6:32452

14. Coda R, Melama L, Rizzello CG, Curiel JA, Sibakov J, Holopainen U, Pulkkinen M, Sozer N (2015) Int J Food Microbiol 193:34-42

15. Chevion M, Navok T, Glaser G, Mager J (1982) Eur J Biochem 127:405-409

16. Marquardt RR, Frohlich AA (1981) J Chromatogr A 208:373-379

17. Marquardt RR, Frohlich AA, Arbid MSS (1989) J Agric Food Chem 37:455-462

18. Marquardt RR, Arbid MSS, Frohlich AA (1989) J Agric Food Chem 37:448-454

19. Pavlik M, Vanova M, Laudova V, Harmatha J (2002) Rostl Vyroba 48:543-547

20. Desroches P, Mandon N, Baehr JC, Huignard J (1997) J Insect Physiol 43:439-446

21. Ketudat Cairns JR, Esen A (2010) Cell Mol Life Sci 67:3389-3405

22. Arese P, De Flora A (1990) Semin Hematol 27:1-40

23. Di Cagno R, Mazzacane F, Rizello CG, Vincentini O, Silano M, Giuliano G, De Angelis M, Gobbetti M (2010) J Agric Food Chem 58:10338-10346

24. Grimaldi A, Bartowsky E, Jiranek V (2005) J Appl Microbiol 99:1061-1069

25. Michlmayr H, Schuemann C, da Silva NMBB, Kulbe KD, del Hierro AM (2010) J Appl Microbiol 108:550-559

26. Verni M, Wang C, Montemurro M, De Angelis M, Katina K, Rizzello CG, Coda R (2017) Front Microbiol 8:2461

27. Sestelo ABF, Poza M, Villa TG (2004) World J Microbiol Biotechnol 20:633-637

28. Michlmayr H, Kneifel W (2014) FEMS Microbiol Lett 352:1-10

29. Rizzello CG, Calasso M, Campanella D, De Angelis M, Gobbetti M (2014) Int J Food Microbiol 180:78-87

30. Coda R, Varis J, Verni M, Rizzello CG, Katina K (2017) LWT Food Sci Technol 82:296-302

31. Lizarazo CI, Lampi A, Liu J, Sontag-Strohm T, Piironen V, Stoddard FL (2015) J Sci Food Agric 95:2053-2064

32. American Association of Cereal Chemists, AACC (1994) AACC method 44-15A. Moisture-Air-oven methods. Approved Methods of the American Assn. of Cereal Chemist. AACC, St Paul, Minnesota

33. Coda R, Kianjam M, Pontonio E, Verni M, Di Cagno R, Katina K, Rizzello CG, Gobbetti M (2017) Int J Food Microbiol 248:10-21

34. Chamlagain B, Deptula P, Edelmann M, Kariluoto S, Grattepanche F, Lacroix C, Varmanen P, Piironen V (2016) LWT Food Sci Technol 72:117-124

35. Pulkkinen M, Gautam M, Lampi A, Ollilainen V, Stoddard F, Sontag-Strohm T, Salovaara H, Piironen V (2015) Food Res Int 76:168-177 
36. Marquardt RR, Muduuli DS, Frohlich AA (1983) J Agric Food Chem 31:839-844

37. Gallo V, Skorokhod OA, Simula LF, Marrocco T, Tambini E, Schwarzer E, Marget P, Duc G, Arese P (2018) Blood $131: 1621-1625$

38. Katina K, Poutanen K, Autio K (2004) Cereal Chem 81:598-610

39. Katina K, Heiniö R, Autio K, Poutanen K (2006) LWT Food Sci Technol 39:1189-1202

40. Riedl KM, Zhang YC, Schwartz SJ, Vodovotz Y (2005) J Agric Food Chem 53:8253-8258
41. Inamdar AN, Kaplan JG (1966) Can J Biochem 44:1099-1108

Publisher's Note Springer Nature remains neutral with regard to jurisdictional claims in published maps and institutional affiliations. 